Sociology of Communication and Methods of Social Research in Communication (in times of COVID19)

\title{
100 Readings for Sociology of Communication
}

Frederic Guerrero-Sole

Published on: Mar 17,2020

DOI: $10.21428 /$ fcdf9a9f.48f59138

License: Creative Commons Attribution 4.0 International License (CC-BY 4.0). 
40 Readings for the Sociology of Communication

S01. [DISCIPLINE]. 00. Weber, Max. Preliminary Report on a Proposed Survey for a Sociology of the Press

S01. [DISCIPLINE]. 01. Sociology of Communicationt

S01.[DISCIPLINE]. 1933. HERBERT_BLUMER_Movies_and_Conduct

S01. [GENDER]. 01. The Founding Mothers of Communication Research

S01. [GENDER]. 02. Herta Herzog and the Founding Mothers of Communication Researchby_Peter_Simonson_

S01. [MAGIC BULLET]. 00. Lasswell. 1927. The Theory of Political Propaganda S01. [MAGIC BULLET]. 01. Not Likely Sent. The Remington-Hearst Telegrams S01.[MAGIC BULLET]. 02. Cantril_Gaudet_Herzog_Invasion_of_Mars_Ch2-3 S01. [MAGIC BULLET]. 03. Goebbel_s Principles of Propaganda S01.[MAGIC BULLET]. 04. Cantril_Gaudet_Herzog_Invasion_of_Mars_Complete Astudy-in-the-psychology-

S01. [MAGIC BULLET]. 05. The Myth of_Massive_Media_impact_McGuire S01. [MORAL PANICS]. 01. [1999] [Drotner] Dangerous Media. Panic Discourses and Dilemmas of Modernity

S01. [MORAL PANICS]. 02. Moral Panic and Reading_2016

S01. [MORAL PANICS]. 03. Havelock_Eric_A_Preface_to_Plato

S01. [MORAL PANICS]. 04. Characteristics_of_Oral_Culture

S02. [FUNCTIONALISM]. 00. Lasswell.The structure and function of communication S02. [FUNCTIONALISM]. 01. Mass Communication Popular Taste and Organized Social Action_Lazarsfeld_Merton

S02. [FUNCTIONALISM]. 02. Lazarsfeld_Merton_Friendship_As_ Social_Process_HOMOPHILY 
S02. [FUNCTIONALISM]. 03. American Communication Research. 14. The History Reconsidered

S02. [FUNCTIONALISM]. 04. Stanton Lazarsfeld and Merton

S02. [FUNCTIONALISM]. 05. 2001. Katz. Lazarsfeld's map of media effects S03. [MEDIA EFFECTS]. 00. [CULTIVATION]. 1978. Gerbner et al. Cultivation Theory S03. [MEDIA EFFECTS]. 01.[AGENDA-SETTING]. Agenda_Framing_Priming S03. [MEDIA EFFECTS]. 02. [THIRD-PERSON EFFECT]. Davison, 1983 TPE S03. [MEDIA EFFECTS]. 03. [SPIRAL OF SILENCE]. Simpson. Spiral of Silence in Historical Context

S03. [MEDIA EFFECTS]. 04. [ADVERTISING]. The Third-Person Effect in Advertising A Meta-Analysis. TPE

S03. [MEDIA EFFECTS]. 05. [ADVERTISING]. PRIMING_2007_

S04. [MEDIA EFFECTS] [CATHARSIS]. 01. Television Violence and Viewer Aggression. CATHARSIS

S04. [MEDIA EFFECTS]. [DECISION FRAMING/DECISION MAKING]. 02. Tversky, Kahneman. 1981. The Framing of Decisions and the Psychology of Choice S04. [USES AND GRATIFICATIONS]. 01. Uses and gratifications Research_Katz_Blumler_Gurevich_1974 S05. [SYMBOLIC INTERACTIONISM]. 01. [GOFFMAN]. Rampton_2018._Goffman_Key_Concepts S05. [SYMBOLIC INTERACTIONISM]. 02. 1999. Nike's Communication with Black Audiences. A Sociological Analysis of Advertising Effectiveness via Symbolic Interactionism.pdf

S07. [CRITICAL]. 00. Lazarsfeld and Adorno in the United States A Case S07.[CRITICAL]. 01. Adorno_A_Social_Critique_of_Radio_Music_ S07. [CRITICAL]. 02. Fuchs_2018_Capitalism, Patriarchy, Slavery S08. [CULTURAL STUDIES]. 01. Encoding-Decoding. Stuart Hall_ORIGINAL 
S09. [DIGITAL MEDIA THEORIES]. 01. boyd danah. ItsComplicated

S09. [DIGITAL MEDIA THEORIES]. 02. Capitalism's New Clothes _ Evgeny Morozov

S09. [DIGITAL MEDIA THEORIES]. 03. Zuboff_Shoshana_The Age of Surveillance Capitalism

S10. [DISCUSSION]. 01. Homophily_ The Urban History of an Algorithm - e-flux Architecture - e-flux 